ORIGINAL ARTICLE

\title{
Detection of human papillomavirus DNA in oral inverted ductal papillomas
}

\author{
C Haberland-Carrodeguas, M L Fornatora, R F Reich, P D Freedman
}

See end of article for authors' affiliations

....................

Correspondence to: Associate Professor M L Fornatora, Temple University School of Dentistry, 3223 North Broad Street, Philadelphia, PA19140, USA; mfornatora@dental. temple.edu

Accepted for publication 27 March 2003

\begin{abstract}
Aims: To determine the presence or absence of human papillomavirus (HPV) DNA in oral inverted ductal papillomas (IDPs) using in situ hybridisation (ISH), and to analyse all cases for histological features of HPV infection.

Methods: Six cases were retrieved from archival material and paraffin wax blocks were submitted for the detection of HPV DNA by means of ISH. A wide spectrum probe for HPV subtypes 6, 11, 16, 18, 31, 33, 45,51 , and 52 was used initially. Cases that were positive using this wide spectrum probe were further subtyped using HPV type specific probes $(6 / 11,16 / 18$, and $31 / 33)$. The histological features of all tumours were analysed using routine microscopy.

Results: Of the six cases of oral IDP identified, three were positive for HPV subtypes 6/11. All positive cases showed histological features of HPV infection (koilocytosis, papillomatosis, binucleated keratinocytes, and abnormal mitosis) in both the surface and the inverted epithelium. The three cases that tested negative for HPV DNA also exhibited focal histological features of HPV infection (two in the surface epithelium and one in the endophytic epithelium).

Conclusions: These are the first documented cases of oral IDP to demonstrate positivity for HPV DNA and also to show histological features of HPV infection.
\end{abstract}

O ral inverted ductal papillomas (IDPs) are benign tumours that are thought to arise from the terminal portions of the excretory ducts of minor salivary glands. In 1982, White et al formally introduced the term IDP to describe these lesions. ${ }^{1}$ The name was chosen for these lesions because of a histological similarity to inverted papillomas of the sinonasal tract. Only 33 cases of this tumour have been reported to date, many of which were described in case reports. ${ }^{1-11}$ Clinically, IDPs present as soft tissue masses with either a smooth or papillary surface. They occur over a wide age range (28-77 years) and have a slight female predilection $(2.2: 1)$. The most common locations are the lip, buccal mucosa, palate, and the floor of the mouth. These tumours are treated by surgical excision. Brannon's review of the literature ${ }^{11}$ found that 12 of the 33 reported cases included follow up, and none of these 12 cases were found to recur in follow up that ranged from three months to 240 months.

\section{"Review of the literature reveals only two case reports of oral inverted ductal papilloma that were examined for human papillomavirus DNA"}

Histologically, oral IDPs are well circumscribed, cup shaped, endophytic epithelial tumours with pushing borders. The bulbous endophytic epithelial proliferations extend into a central lumen as papillary projections. In most lesions, the endophytic epithelial component is contiguous with the surface epithelium. The endophytic epithelium is composed primarily of squamous cells, but both ciliated columnar and cuboidal epithelial cells, in addition to mucous cells, can be seen. Microcysts, containing mucous and polymorphonuclear leucocytes, are commonly seen. Nuclear pleomorphism and mitotic figures are rare. ${ }^{312}$ Histological features of human papillomavirus (HPV) infection (koilocytosis, binucleated keratinocytes, abnormal mitoses, etc) have not been reported in association with oral IDP.
There have been no reports of the identification of HPV DNA in oral IDP. Review of the literature reveals only two case reports of oral IDP that were examined for HPV DNA. Both cases were found to be negative. ${ }^{8}{ }^{10}$ Neither author commented on the presence or absence of histological features of HPV infection. In contrast, sinonasal papillomas have been studied extensively for their association with HPV. Syrjänen et al first suggested the association between sinonasal papillomas and HPV in their 1983 report. ${ }^{13}$ Since that initial report, the results of numerous studies have been published, which document HPV testing in over 1000 sinonasal papillomas. Collectively, HPV was identified in $33.3 \%$ of these sinonasal papillomas, as determined by various detection methods (polymerase chain reaction (PCR) and hybridisation techniques). ${ }^{14}$ HPV types 6 and 11 have been the most frequently identified HPV subtypes in sinonasal papillomas. ${ }^{14-16}$

We present a series of six cases of oral IDP that have been evaluated for HPV DNA using in situ hybridisation (ISH) and studied for histological features of HPV infection using routine light microscopy.

\section{METHODS}

\section{Biopsy material}

Six formalin fixed, paraffin wax embedded biopsy specimens of oral IDP were retrieved from archival material (Oral Pathology Laboratories, New York, USA). Sections of each case were stained with haematoxylin and eosin and the histological diagnoses were reviewed using recognised morphological criteria for oral IDP. In addition, each case was reviewed for histological features of HPV infection (koilocytosis, binucleated keratinocytes, abnormal mitosis,

Abbreviations: HPV, human papillomavirus; IDP, inverted ductal papilloma; ISH, in situ hybridisation; PCR, polymerase chain reaction 


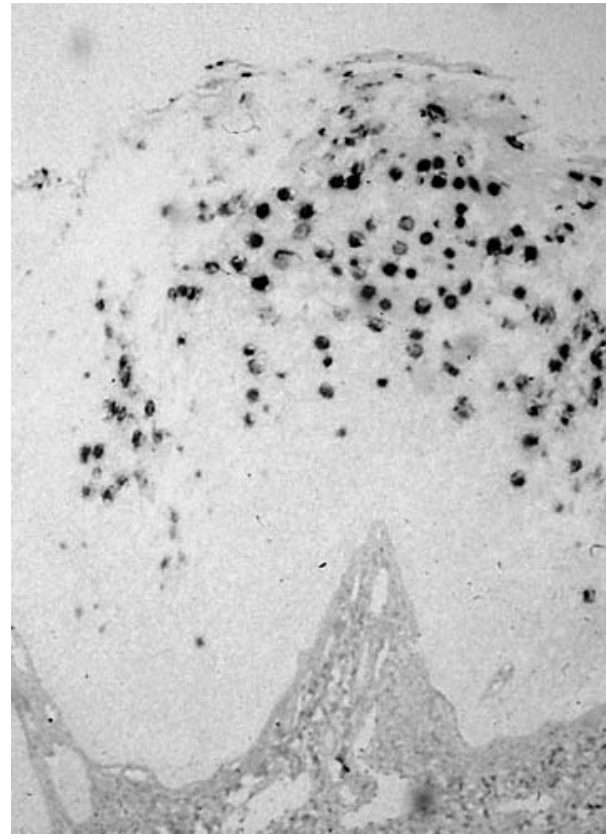

Figure 1 Surface positivity in oral inverted papilloma (case 6) using a wide spectrum human papillomavirus (HPV) DNA probe and in situ hybridisation. The wide spectrum probe detects HPV types $6,11,16,18$, $30,31,33,45,51$, and 52 .

and papillomatosis), both in the surface epithelium and in the endophytic portions of the tumours.

\section{In situ hybridisation}

Additional sections were obtained for the purpose of HPV DNA hybridisation studies using commercially available probes. Initially, a wide spectrum biotinylated probe (Dako, Carpinteria, California, USA) for common HPV types was used, according to the manufacturer's suggested protocol (Dako GenPoint K0620 catalysed signal amplification system for in situ hybridisation; Dako). The wide spectrum probe (Y1404) targets the genomic DNA of HPV types 6, 11, 16, 18, $30,31,33,35,45,51$, and 52. Further subtyping was carried out on cases found to be positive using the wide spectrum probe. Three type specific probes for HPV 6/11 (Y1411), HPV 31/33 (Y1413), and HPV 16/18 (Y1412) were used for subtyping.

\section{RESULTS}

Of the six cases of oral IDP identified from archival material, there was an equal sex distribution, with three cases

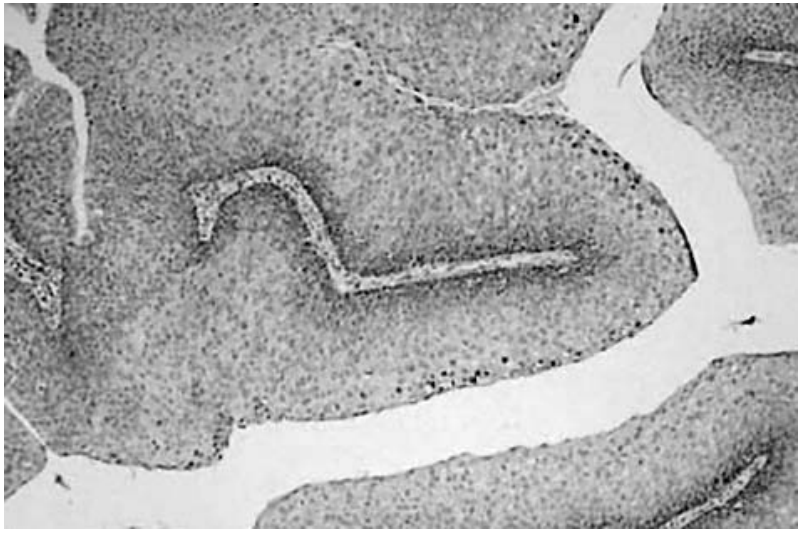

Figure 2 Positive DNA in situ hybridisation for human papillomavirus $6 / 11$ in the endophytic component of oral inverted ductal papilloma (case 5).

occurring in men and three in women. The age range was 27 to 57 years (mean, 43). The most common location was the lip, followed by the floor of the mouth.

\section{In situ hybridisation}

Three of the six cases tested were positive for HPV DNA using the wide spectrum probe. All positive cases were further characterised for HPV subtypes, and all were shown to contain HPV types 6/11. All cases were negative for HPV subtypes $31 / 33$ and $16 / 18$. Positivity for HPV DNA was noted in all three cases, both in the surface epithelium (fig 1) and the endophytic epithelium (fig 2). Table l summarises the results of the ISH analysis and also includes the clinical data.

\section{Light microscopy}

All six cases showed classic features of oral IDP (fig 3). Five of six cases exhibited histological features of HPV infection. Table 1 details the histological features of HPV infection that were found in the surface and submucosal portions of the tumour for each of the six cases. Five cases showed features of HPV infection in the surface epithelium consistent with papillomatosis, koilocytosis, and binucleated keratinocytes (fig 4). Three of these cases were positive for HPV DNA. Four cases had features of HPV infection in the endophytic component; three of these were found to contain HPV DNA (fig 5). No histological evidence of epithelial dysplasia was noted.

\section{DISCUSSION}

Oral IDPs are non-aggressive benign growths with no reported potential to undergo malignant transformation.

Table 1 Summary of clinical information and results of in situ hybridisation for human papillomavirus (HPV) DNA in the six cases of oral inverted ductal papilloma

\begin{tabular}{|c|c|c|c|c|c|c|c|c|}
\hline Case & Sex & Age & Location & $\begin{array}{l}\text { Histological features } \\
\text { of HPV infection }\end{array}$ & $\begin{array}{l}\text { HPV WSS } \\
\text { probe }\end{array}$ & $\begin{array}{l}\text { HPV } \\
6 / 11\end{array}$ & $\begin{array}{l}\text { HPV } \\
16 / 18\end{array}$ & $\begin{array}{l}\text { HPV } \\
31 / 33\end{array}$ \\
\hline 1 & $\mathrm{~F}$ & 27 & Soft palate & Present in surface epithelium & - & - & - & - \\
\hline 2 & $\mathrm{~F}$ & 57 & $\begin{array}{l}\text { Upper labial } \\
\text { mucosa }\end{array}$ & None present & - & - & - & - \\
\hline 3 & $\mathrm{~F}$ & 39 & $\begin{array}{l}\text { Right buccal } \\
\text { mucosa }\end{array}$ & $\begin{array}{l}\text { Present in surface epithelium and } \\
\text { endophytic component }\end{array}$ & - & - & - & - \\
\hline 4 & M & 39 & Floor of mouth & $\begin{array}{l}\text { Present in surface epithelium and } \\
\text { endophytic component }\end{array}$ & + & + & - & - \\
\hline 5 & M & 41 & Floor of mouth & $\begin{array}{l}\text { Present in surface epithelium and } \\
\text { endophytic component }\end{array}$ & + & + & - & - \\
\hline 6 & M & 54 & $\begin{array}{l}\text { Right buccal } \\
\text { mucosa }\end{array}$ & $\begin{array}{l}\text { Present in surface epithelium and } \\
\text { endophytic component }\end{array}$ & + & + & - & - \\
\hline
\end{tabular}

WSS, wide spectrum probe; includes HPV types 6, 11, 16, 18, 30, 31, 33, 45, 51, and 52 . 


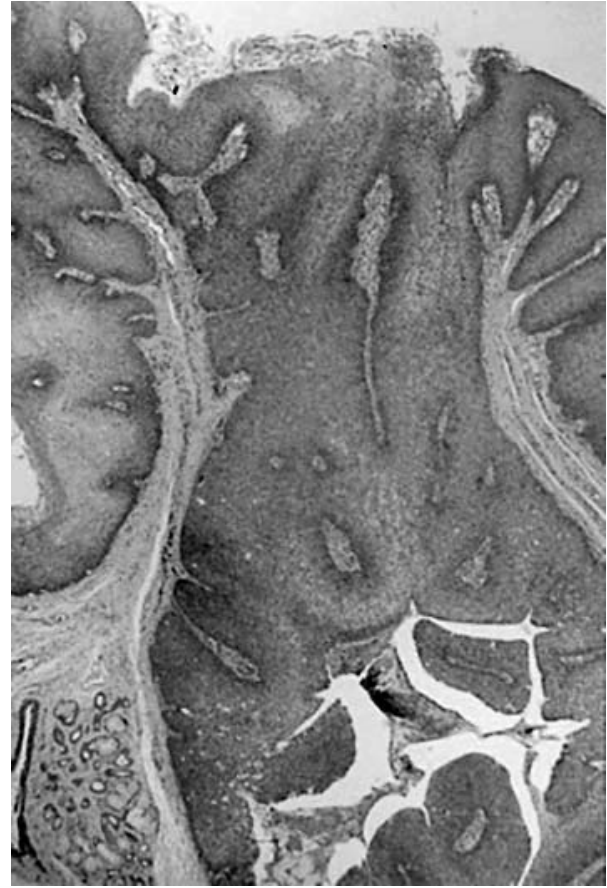

Figure 3 Haematoxylin and eosin stained section showing the classic histological features of oral inverted ductal papilloma.

They present clinically as small, isolated, well defined nodules, which do not recur after conservative local excision. ${ }^{11}$ Our study identified light microscopic features of HPV infection in five of the six cases studied and detected HPV 6/11 DNA in three of them. This is the first report documenting the presence of HPV DNA in oral IDP. To date, in only two case reports of oral IDP were the samples tested for HPV DNA. One study used ISH as a detection method for HPV DNA, whereas the other used PCR. Both cases were found to be negative. ${ }^{8} 10$

Although there is a histological similarity between oral IDP and sinonasal inverted papilloma, the clinical presentation and prognosis are considerably different. Histological features common to both tumours include an endophytic proliferation of broad papillary projections composed of stratified squamous epithelium containing microcysts and mucous cells. Although sinonasal inverted papillomas are predominantly endophytic, they may present with an

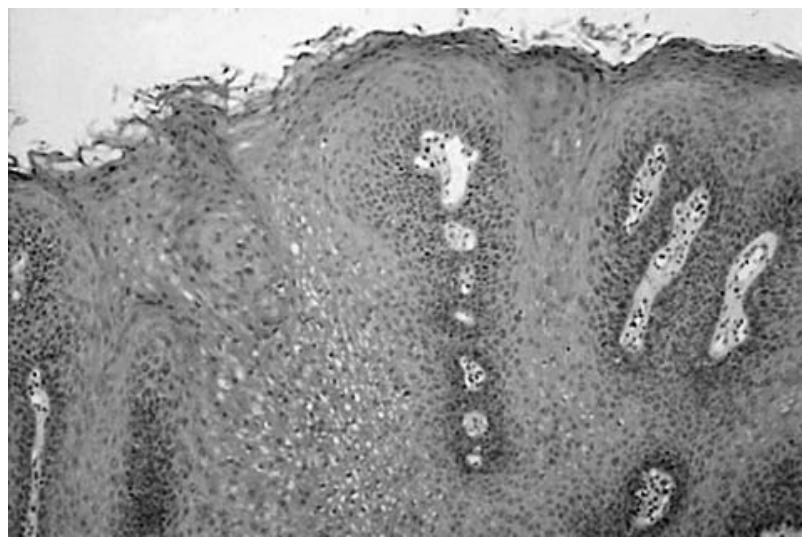

Figure 4 Histological features of human papillomavirus infection, including hyperkeratosis, papillomatosis, and koilocytosis seen in the surface component of this oral inverted papilloma.

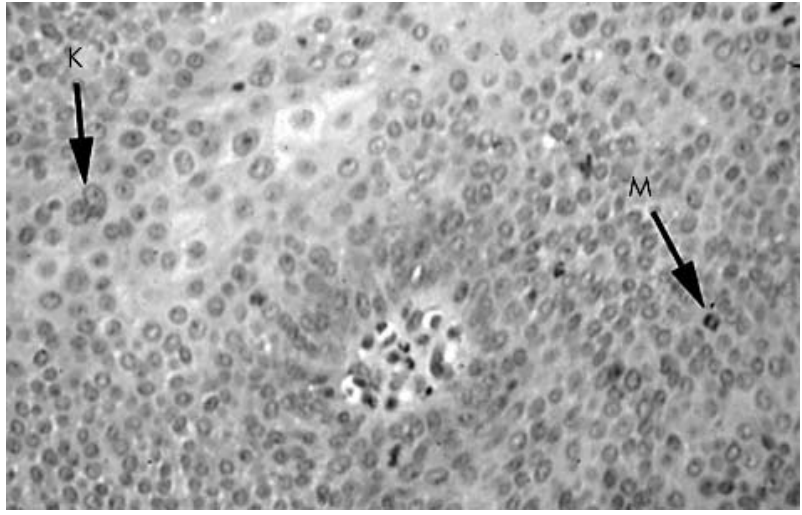

Figure 5 Histological features of human papillomavirus infection seen in the endophytic component of oral inverted ductal papilloma. Features include binucleated keratinocytes $(K)$ and abnormal mitotic figures $(M)$. Elsewhere, koilocytes were seen in the overlying surface epithelium and in the endophytic portion.

exophytic component. ${ }^{17}$ In contrast to the stratified squamous surface epithelium of oral IDPs, sinonasal inverted papillomas present with columnar ciliated epithelium, reflecting their site of origin. Sinonasal inverted papillomas have a high recurrence rate after excision, pose a risk for malignant transformation, ${ }^{18}$ and present in a multicentric manner. ${ }^{19}$ As already stated, multiple investigators have documented the presence of HPV DNA in these lesions. ${ }^{13-16}$ Most often, researchers have identified HPV subtypes 6/11 in benign sinonasal inverted papillomas, but HPV types 16/18 have also been documented infrequently, including cases associated with squamous cell carcinoma. ${ }^{20}{ }^{21}$

\section{"Although there is a histological similarity between oral inverted ductal papilloma and sinonasal inverted papil- loma, the clinical presentation and prognosis are con- siderably different"}

The detection of light microscopic features of HPV infection in otherwise "routine" oral IDP prompted our investigation of archival cases for the presence of HPV DNA. Five of the six archival cases studied proved to exhibit light microscopic features of HPV infection, including koilocytosis, binucleated keratinocytes, increased mitotic activity, and abnormal mitoses. These features have been reported in cases of sinonasal inverted papilloma, ${ }^{22}$ but not in oral IDP. Our results show a correlation between light microscopic features of HPV infection and the detection of HPV DNA by ISH in three of the six lesions. Failure to detect HPV DNA in the remaining three cases may reflect a varied aetiology and pathogenesis for these tumours. It is also possible that these cases represent false negatives. The potential for false negative results is a valid consideration because ISH is unable to detect low copy numbers of HPV DNA. ${ }^{23}{ }^{24}$ It is also possible that the negative cases contained HPV subtypes other than those that were investigated.

The exact role of HPV in the aetiology and pathogenesis of these oral tumours is equivocal. The reported prevalence of HPV in normal mucosa varies between studies depending on sample collection technique, age, sex, and HPV detection methods. According to data compiled by Syrjänen and Syrjänen from a total of 24 studies of normal oral mucosa, the prevalence of HPV in normal mucosa is approximately $11 \%{ }^{25}$ Consequently, there is a potential for the incidental identification of the virus in an otherwise unrelated pathological process. 


\section{Take home messages}

- Three of the six cases of oral inverted ductal papilloma (IDP) studied were positive for human papillomavirus (HPV) subtypes 6/11

- All positive cases showed histological features of HPV infection in both the surface and the inverted epithelium

- The three cases that tested negative for HPV DNA also exhibited focal histological features of HPV infection (two in the surface epithelium and one in the endophytic epithelium)

- These are the first documented cases of oral IDP to demonstrate positivity for HPV DNA and also to show histological features of HPV infection.

- The exact role of HPV in the pathogenesis of these tumours remains to be understood

\section{CONCLUSIONS}

In conclusion, we present the first reported cases of oral IDP with both histological features of HPV infection and confirmed positivity for HPV DNA. The exact role of HPV in the pathogenesis of these tumours remains to be understood.

\section{ACKNOWLEDGEMENTS}

We wish to acknowledge the helpful advice of Professor L MacPhail, Rosenthal Endowed Chair in Oral Medicine, Temple University School of Dentistry. This project was supported in part by funds from the Rosenthal Endowed Chair in Oral Medicine.

\section{Authors' affiliations}

C Haberland-Carrodeguas, M L Fornatora, Temple University School of Dentistry, 3223 North Broad Street, Philadelphia, PA19140, USA

R F Reich, P D Freedman, The New York Hospital, Medical Center of Queens, Section of Oral Pathology, 56-45 Main Street, Flushing, New York, 11355, USA

\section{REFERENCES}

1 White DK, Miller AS, McDaniel RK, et al. Inverted ductal papilloma: a distinctive lesion of minor salivary gland. Cancer 1982;49:519-24.

2 Regezi JA, Lloyd RV, Zarbo RJ, et al. Minor salivary gland tumors. A histologic and immunohistochemical study. Cancer 1985;55:108-15.
3 Ellis GL, Auclair PL, Tumors of the salivary glands. In: Rosai J, Sobin LH, eds. Atlas of tumor pathology, Series 3, Fascicle 17. Washington DC: Armed Forces Institute of Pathology, 1996:120-30.

4 Wilson DF, Robinson BW. Oral inverted ductal papilloma. Oral Surg Oral Med Oral Pathol 1984:57:520-3.

5 Clark DB, Priddy RW, Swanson AE. Oral inverted ductal papilloma. Oral Surg Oral Med Oral Pathol 1990;69:487-90.

6 Batsakis JG. Oral monomorphic adenomas. Ann Otol Rhinol Laryngol $1991 ; 100: 348-50$

7 Franklin CD, Ong TK. Ductal papilloma of the minor salivary gland. Histopathology 1991;19:180-2.

8 Koutlas IG, Jessurun J, lamaroon A. Immunohistochemical evaluation and in situ hybridisation in a case of oral inverted ductal papilloma. J Oral Maxillofac Surg 1994;52:503-6.

9 Hegarty DJ, Hopper C, Speight PM. Inverted ductal papilloma of minor salivary glands. J Oral Pathol Med 1994;23:334-6.

10 Scolyer RA, Rose B, Painter DM. Test and teach. Number 96.Part 1. Inverted duct papilloma of minor salivary gland origin. Pathology 1999;31:372, 423-4.

11 Brannon RB, Sciubba JJ, Giuliani M. Ductal papillomas of salivary gland origin: a report of 19 cases and a review of the literature. Oral Surg Oral Med Oral Pathol Oral Radiol Endod 2001;92:68-77.

12 Ellis GL, Auclair PL. Ductal papillomas. In: Ellis GL, Auclair PL, Gnepp DR, eds. Surgical pathology of the salivary glands. Philadelphia: WB Saunders, 1991:238-52.

13 Syriänen KJ, Pyrhonen S, Syrïänen SM. Evidence suggesting human papillomavirus (HPV) etiology for the squamous cell papilloma of the paranasal sinus. Arch Geschwulstforsch 1983:53:77-82.

14 Syriänen KJ. HPV infections in benign and malignant sinonasal lesions. J Clin Pathol 2003;56:174-81.

15 Shen J, Tate JE, Crum CP, et al. Prevalence of human papillomavirus (HPV) in benign and malignant fumors of the upper respiratory tract. Mod Pathol 1996;9:15-20.

16 Syriänen K, Syriänen S. HPV infection of the respiratory tract. Papillomavirus infections in human pathology. Chichester, England: John Wiley \& Sons Ltd, 2000:359-63

17 Mills SE, Gaffey MJ, Frierson HF Jr. Tumors of the upper aerodigestive tract and ear. In: Rosai J, Sobin LH, eds. Atlas of tumor pathology, Series 3, Fascicle 26. Washington DC: Armed Forces Institute of Pathology, 1997:22-6.

18 Batsakis JG, Suarez P. Schneiderian papillomas and carcinomas: a review. Adv Anat Pathol 2001:8:53-64.

19 Christensen WN, Smith RR. Schneiderian papillomas: a clinicopathologic study of 67 cases. Hum Pathol 1986;17:393-400.

20 Brandwein $M$, Steinberg B, Thung $S$, et al. Human papillomavirus $6 / 11$ and $16 / 18$ in schneiderian inverted papillomas. In situ hybridisation with human papillomavirus RNA probes. Cancer 1989;63:1708-13.

21 Kashima HK, Kessis T, Hruban RH, et al. Human papillomavirus in sinonasal papillomas and squamous cell carcinoma. Laryngoscope 1992;102:973-6.

22 Beck JC, McClatchey KD, Lesperance MM, et al. Presence of human papillomavirus predicts recurrence of inverted papilloma. Otolaryngol Head Neck Surg 1995; 113:49-55.

23 Nuovo GJ. PCR in situ hybridisation: protocols and applications. New York: Raven Press, 1992.

24 Bernard C, Mourgin C, Bettinger D, et al. Detection of human papillomavirus by in situ polymerase chain reaction in paraffin-embedded cervical biopsies. Mol Cell Probes 1994;8:337-43.

25 Syriänen K, Syriänen S. HPV infection of the oral Mucose. Papillomavirus infections in human pathology. Chichester, England: John Wiley \& Sons Ltd, 2000:380 